\title{
Advances in the diagnosis of GERD
}

\author{
ELENA-ROXANA SĂRARU ${ }^{1,2}$, VLAD ENCIU $^{1,2}$, RAZVAN PEAGU $^{1,2}$, \\ CARMEN FIERBINȚEANU-BRATICEVICI ${ }^{1,2}$ \\ ${ }^{1}$ University Emergency Hospital Bucharest, Gastroenterology Department, Bucharest, Romania \\ 2 "Carol Davila" University of Medicine and Pharmacy, Bucharest, Romania
}

\begin{abstract}
Gastroesophageal reflux disease (GERD) is considered one of the most frequent chronic gastrointestinal diseases globally with high costs due to treatment and investigations.

First line therapy is with proton pump inhibitors, those who do not respond to initial treatment usually require further investigations such as upper gastrointestinal endoscopy or ambulatory 24-hours esophageal $\mathrm{pH}$ monitoring. The total time of exposure to acid and the DeMeester score represent the most useful parameters associated with conventional $\mathrm{pH}$-metry, because they can identify gastroesophageal reflux disease.

Although pH-metry is considered the gold standard for the evaluation of gastroesophageal reflux disease, new impedance-based parameters have been introduced in recent years with the role of increasing the accuracy of diagnosing gastroesophageal reflux disease and characterizing the type of reflux. The development of multichannel intraluminal $\mathrm{pH}$-impedance has improved the ability to detect and quantify gastroesophageal reflux. New parameters such as post-reflux swallowing peristaltic wave (PSPW) index and the mean nocturnal basal impedance (MNBI) have recently been introduced to assess GERD phenotypes more accurately. This review evaluates current GERD diagnotic tools while also taking a brief look at newer diagnostic parameters like PSPW and MNBI.
\end{abstract}

Key words: gastroesophageal reflux disease, pH-metry, multichannel intraluminal pH-impedance, PSPW index, MNBI.

\section{INTRODUCTION}

Gastroesophageal reflux disease (GERD), according to the 2006 Montreal Consensus, is defined as a chronic condition that develops when the reflux of gastric contents into the proximal and distal esophagus causes symptoms and/or complications associated with it, affecting daily activity, and occurring at least twice a week [1].

GERD is one of the most common gastrointestinal diseases worldwide, it has an estimated global prevalence of $8-33 \%$ and is a digestive disorder that affects all age groups and both sexes [2]. It is considered one of the most expensive gastrointestinal pathologies, the high costs are mainly due to proton pump inhibitor (PPI) treatments, but also to complex diagnostic methods, frequent healthcare appointments and referrals. In the United States of America, costs have been estimated at around 9-10 billion $\$$ per year [3].

The objectives of this article are to evaluate current GERD diagnostic tools while also taking a brief look at newer diagnostic parameters like postreflux swallow-induced peristaltic wave index (PSPW) and mean nocturnal basal impedance (MNBI).

\section{DIAGNOSTIC INVESTIGATIONS IN GASTROESOPHAGEAL REFLUX DISEASE}

GERD is a complex disease with multiple phenotypes that may require multiple steps to correctly evaluate. GERD is initially evaluated based on the presence of typical symptoms (heartburn, acid regurgitation) or atypical symptoms (chest pain, chronic cough, asthma-like symptoms, sinusitis). An adjacent GERD questionnaire (GERDQ) can be used to guide the diagnosis. If no alarm symptoms (dysphagia, anemia, weight loss, upper gastrointestinal bleeding, persistent vomiting) are present then patients can begin a PPI trial [4]. Proton pump inhibitors have been universally accepted as the first line of treatment in the management of gastroesophageal reflux disease. The response to the PPI trial guides subsequent treatment, if patients respond to treatment then physicians should taper PPI to lowest possible dose. In the absence of a complete response to empirical PPI therapy, the dose of PPI is normally doubled [4]. In patients who still do not notice improvements in reflux symptoms, upper gastrointestinal endoscopy should be considered. Upper gastrointestinal endoscopy should also be the first line for patients presenting with alarm symptoms. 
If no abnormalities are found after upper gastrointestinal endoscopy, then $\mathrm{pH}$ monitoring should be performed to provide further information. High-resolution impedance manometry with or without $\mathrm{pH}$ impedance can provide additional information if GERD phenotype is uncertain after conventional $\mathrm{pH}$ monitoring [5]. An algorithm for diagnosing GERD is shown in Figure 1.

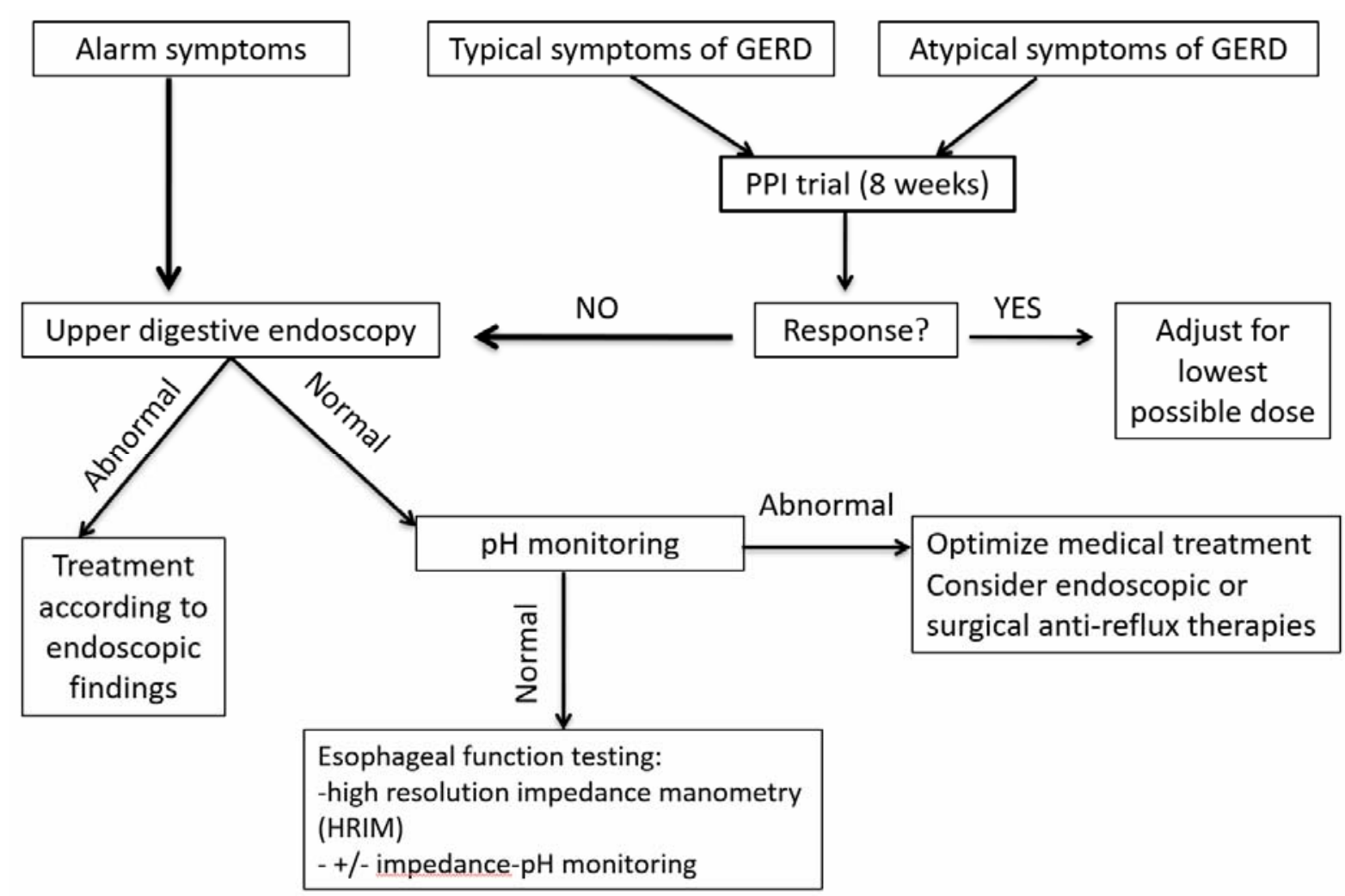

Figure 1. Algorithm for GERD diagnosis

\section{AMBULATORY 24-HOUR ESOPHAGEAL PH MONITORING}

Monitoring of esophageal $\mathrm{pH}$ was developed in 1960, but entered clinical practice only in 1970 . The association between esophageal mucosa damage and the presence of gastroesophageal reflux was the first one to be evaluated. Thus, in 1958, Tuttle and Grossman were the first to assess the presence of acid reflux at the esophageal level, using a $\mathrm{pH}$ meter with manometry [6-8].

In 1974, Johnson and DeMeester helped create the basis for monitoring esophageal $\mathrm{pH}$, following the evaluation of patients with reflux symptoms and healthy subjects. They established the methodology of proper monitoring of the esophageal $\mathrm{pH}$, added reference values and created the DeMeester composite score (DMS) as a way of grading GERD [6].

Outpatient monitoring of esophageal $\mathrm{pH}$ can directly quantify esophageal acid exposure, subsequently it is a great method of evaluating patients who do not respond to PPI therapy, patients with atypical symptoms of reflux disease and can also be used for the preoperative evaluation of patients undergoing anti-reflux surgery procedures $[4,9,10]$.

Ambulatory 24-hour esophageal $\mathrm{pH}$ monitoring allows the direct measurement of total time of esophageal exposure to acid, highlights the frequency of reflux episodes and can highlight associations between the symptoms and the occurrence of reflux episodes.

The main indications for 24-hour esophageal $\mathrm{pH}$ monitoring are represented by:

- Patients refractory to empirical PPI therapy

- Patients with reflux symptoms with no endoscopic changes

- Preoperative evaluation for antireflux surgery $[4,11]$.

Conventional pH-monitoring consists in measuring the esophageal acidity for 24 hours using a catheter with $\mathrm{pH}$ sensitive electrodes, introduced intranasally to the level right above the lower esophageal sphincter (SEI). Table 1 illustrates the main advantages and disadvantages of conventional $\mathrm{pH}$-monitoring. 
Table 1

Comparison between conventional $\mathrm{pH}$-metry and multichannel-impedance $\mathrm{pH}$-metry

\begin{tabular}{|c|c|c|}
\hline pH-monitoring test & Advantages & Disadvantages \\
\hline Conventional pH-metry & $\begin{array}{l}\text { - easy to mount intranasally, does not } \\
\text { require endoscopic assistance } \\
\text { - easy to interpret results } \\
\text { - can detect acid reflux }\end{array}$ & $\begin{array}{l}\text { - produces certain inconveniences in patient's } \\
\text { daily activity [36] } \\
\text { - can reduce food intake due to its } \\
\text { placement [36] } \\
\text { - cannot detect non-acid reflux } \\
\text { - cannot detect food intake, relies on patient } \\
\text { cooperation to indicate food ingestion } \\
\text { - cannot detect belching syndromes }\end{array}$ \\
\hline Multichannel-impedance pH-metry & $\begin{array}{l}\text { - easy to mount intranasally, does not } \\
\text { require endoscopic assistance } \\
\text { - can distinguish between acid and non- } \\
\text { acid reflux } \\
\text { - can detect food ingestion without patient } \\
\text { assistance } \\
\text { - effective in variety of GERD presentations } \\
\text { including those refractory to PPI therapy } \\
\text { - can diagnose belching syndromes [15] }\end{array}$ & $\begin{array}{l}\text { - produces certain inconveniences in } \\
\text { patient's daily activity [36] } \\
\text { - can reduce food intake due to its } \\
\text { placement [36] } \\
\text { - interpretation of the test is more complex } \\
\text { [15] } \\
\text { - more expensive compared to conventional } \\
\text { pH-metry [20] }\end{array}$ \\
\hline
\end{tabular}

Table 2 shows some of the most used parameters used with conventional $\mathrm{pH}$ monitoring. The DeMeester score is the most used tool to diagnose GERD, it takes into account 6 criteria. [12]. A DeMeester score greater than 14.72 indicates the presence of acid reflux, furthermore the individual evaluation of each parameter is useful for evaluating the reflux pattern, as well as esophageal clearance [13]. A high DeMeester score is also associated with the presence of endoscopic changes caused by esophagitis, hiatal hernia, esophageal motility disorders, while also correlating with the severity of damage to the esophageal mucosa, but also the size of hiatal hernia and the presence of intestinal metaplasia in Barrett's esophagus [13]. The DeMeester score has some limitations such as the fact that it can give false negative results because of catheter-induced hypersalivation or due to gastric alkalization induced by a Helicobacter Pylori infection, but despite these limitations, it remains a sensitive test for GERD [13].

Table 2

Parameters utilized in $\mathrm{pH}$ and $\mathrm{pH}$-impedance monitoring

\begin{tabular}{|c|c|}
\hline Conventional parameters & Description \\
\hline DeMeester Score (DMS) & $\begin{array}{l}\text { Composite score that utilizes } 6 \text { variables: } \\
\text { 1. Percentage of total time with esophageal } \mathrm{pH} \text { under } 4 \\
\text { 2. Percentage of time in upright position with esophageal } \mathrm{pH} \text { under } 4 \\
\text { 3. Percentage of time in supine position with esophageal } \mathrm{pH} \text { under } 4 \\
\text { 4. Number of reflux episodes with } \mathrm{pH} \text { under } 4 \text { in } 24 \text { hours } \\
\text { 5. Number of reflux episodes with } \mathrm{pH} \text { under } 4 \text { that last over } 5 \text { minutes } \\
\text { 6. The longest reflux episode with a pH under } 4\end{array}$ \\
\hline AET (acid exposure time) & Percentage of total time with $\mathrm{pH}$ under 4 at the distal esophageal $\mathrm{pH}$ sensors \\
\hline SI (Symptom Index) & Percentage of reflux episodes that are related to symptoms \\
\hline SAP (Symptom Association Probability) & $\begin{array}{l}\text { Simple statistical method that expands on SI to better reveal correlations } \\
\text { between symptoms and reflux (5) }\end{array}$ \\
\hline \multicolumn{2}{|l|}{ Novel parameters in MII-pH } \\
\hline MNBI (Mean Nocturnal Baseline Impedance) & $\begin{array}{l}\text { Assesses the status of mucosal integrity by determining the average baseline } \\
\text { impedance values measured during nighttime over a period of } 10 \text { minutes at } \\
\text { each impedance sensor (15) }\end{array}$ \\
\hline $\begin{array}{l}\text { PSPW index (Post-reflux swallow-induced } \\
\text { peristaltic wave) }\end{array}$ & $\begin{array}{l}\text { Peristaltic movement after a reflux episode acts as a defense mechanism for the } \\
\text { mucosa. The PSPW index detects if peristalsis occurs after a reflux episode (15) }\end{array}$ \\
\hline
\end{tabular}

Esophageal reflux can also be quantified by the total percent of acid exposure time (AET) at $\mathrm{pH}<4$. AET has been shown to be a useful and reproducible parameter that can differentiate between physiological and pathological reflux $[9,10,14,15]$. A value of AET below 4\%, defines physiological 
acid reflux, while a value $>6 \%$ is considered pathological reflux, and values between $4-6 \%$ are classified as borderline or inconclusive $[9,10]$.

The efficiency of AET and DeMeester score are quite similar with AET achieving an accuracy of $96 \%$, while DeMeester score has showed an accuracy of $98 \%$ in diagnosing GERD [16].

Over time, other diagnostic parameters besides AET and the DeMeester score have been proposed in order to assess GERD such as the symptom index (SI), symptom association probability (SAP) and binomial symptom index (BSI) [10]. Of these, the most utilized parameters have been SAP and SI. SI is defined as the percentage of symptomatic episodes related to reflux, a value of over $50 \%$ usually indicates GERD, while SAP is a based on statistical analysis and reveals the probability of association between symptoms and episodes of reflux [17]. A value of SAP over $95 \%$ or a value of SI over $50 \%$ usually indicates the presence of GERD [13]. BSI is another statistical method similar to SAP that calculates the probability that symptom events and reflux episodes are associated [18]. It is considered that BSI and SAP are closely related and both can be used in the context of correlating symptoms with the onset of reflux episodes, however BSI is rarely used in clinical practice [13]. In summary, SI is a quantitative measure of GERD, while SAP and BSI are a measure of probability of association between symptoms and reflux events.

Conventional $\mathrm{pH}$-monitoring has some contraindications such as low patient cooperation, presence of coagulopathies, patients on anticoagulant or coumarin derivatives treatment, the presence of esophageal ulcers, recent surgery in the gastric sphere, esophageal varices, cardiovascular instability, obstruction or the presence of maxillofacial trauma.

\section{MULTICHANNEL INTRALUMINAL PH-IMPEDANCE (MII-PH)}

Multichannel intraluminal $\mathrm{pH}$-impedance represents a new investigation in the panel for evaluating esophageal function and the diagnosis of GERD. The principles of this technique were first described in 1991 by Silny and consist in detecting the presence of liquids at the esophageal level by measuring the resistance of the electric current in the alternating circuit [19]. The principles are based on Ohm's law, which stipulates that the impedance of the current flow is inversely proportional to the electrical conductivity of the medium through which the current is transmitted. Impedance is measured with the help of 6 pairs of spaced electrodes placed at the level of the esophageal lumen with the role of recording the anterograde and retrograde movements throughout the esophagus [19].

This method can detect the type of bolus (liquid, gas, mixed content) at the esophageal level, based on changes in electrical conductivity regardless of acid content. Thus, if the intraluminal content is represented by air, no electric current will be formed between the 2 metal electrodes (low conductivity), causing high impedance values. Conversely, if the contents of the bolus are liquid, the conductivity increases and the impedance decreases. The technique allows the characterization of the type of gastroesophageal reflux, its chemical composition, the nature of the extension, the speed and time of esophageal clearance. Also, these multichannel intraluminal impedance catheters were made in order to understand whether the content that we detect intraesophageally through a single channel moves from proximal to distal (swallowing) or from distal to proximal (reflux).

Currently, in clinical practice, two types of multichannel intraluminal impedance have been described, namely a combination of this and $\mathrm{pH}$ monitoring (MII-pH) and the association between impedance and high-resolution manometry.

MII-pH can distinguish and characterize the pattern of gastroesophageal reflux with much higher accuracy compared to endoscopy or conventional $\mathrm{pH}$-metry [20]. This investigation is useful in differentiating between acid and non-acid reflux, with acid reflux considered a $\mathrm{pH}<4$, weak acid reflux with $\mathrm{pH}$ between 4-7 and non-acid reflux with $\mathrm{pH}>7$. The association between impedance and $\mathrm{pH}$-metry allows the characterization of the type of reflux, especially in patients with GERD with persistent symptoms despite PPI therapy. Table 1 illustrates the main advantages and disadvantages of MII-pH.

The indications of MII-pH-metry are represented by: confirmation of GERD, identification of weakly acid or non-acid reflux, persistent regurgitation, refractory GERD despite PPI therapy, diagnosis of belching syndromes [15]. For the test to be effective, it is recommended that the $\mathrm{pH}$ impedance device to be used for 24 hours, but international consensus has stipulated that just 16 hours of monitoring are sufficient to obtain sufficient conclusive data for the diagnosis of GERD [10]. Table 2 illustrates the main parameters used in MII-pH, while also describing novel parameters. 


\section{NOVEL METRICS IN PH IMPEDANCE}

In recent years, the usefulness of MII-pH in identifying the phenotypes of gastroesophageal reflux disease has been improved with the help of new parameters, namely: post-reflux swallow-induced peristaltic wave (PSPW) index, which evaluates the effectiveness of esophageal chemical clearance and mean nocturnal basal impedance (MNBI), which assesses the integrity of the esophageal mucosa [21-23]. These parameters increase the accuracy of MII-pH, especially in differentiating patients with GERD from those with functional heartburn [22, 24, 25].

MNBI is considered a marker whose values reflect the permeability of the esophageal mucosa. It is measured over 3 periods of 10 minutes each during sleep (usually after midnight), because swallow and reflux events are generally lower at night and will not alter the results [26]. Low values correlate with lesions of the esophageal mucosa such as erosive esophagitis, Barrett's esophagus, eosinophilic esophagitis and are usually related to changes in intercellular spaces and tight junctions [27, 28]. Low values can also indicate stasis of a food bolus secondary to severe esophageal motility disorders $[29,30]$. MNBI can distinguish GERD from reflux hypersensitivity and functional heartburn [24-26]. MNBI can also differentiate functional heartburn from eosinophilic esophagitis, non-erosive reflux disease (NERD), and reflux hypersensitivity [31].

A recent meta-analysis of 4 studies showed that MNBI had good accuracy in the diagnosis of GERD with an area under the receiver operating characteristic curve (AUROC) of 0.89 (CI 95\%, 0.86-0.91) [32]. Frazzoni et al. in their study based on 289 patients from Italy showed good results for MNBI in diagnosing GERD with AUROC 0.876, furthermore MNBI showed as expected better accuracy in diagnosing erosive reflux than diagnosing non-erosive reflux [24]. Ravi et al. found similar results in patients from the USA, MNBI was an excellent method of assessing GERD with an AUROC of 0.931 with $86.2 \%$ sensitivity, $88.5 \%$ specificity for a cut-off of 1581.9 ohms [33]. One study that included only 52 patients from Germany found that a higher cut-off of 2100 ohms can identify GERD with $78 \%$ sensitivity and $71 \%$ specificity [28]. Hoshikawa et al. pointed out that a cut-off value of $1785 \mathrm{Ohm}$ can distinguish with a sensibility of $80 \%$ and specificity of $89.7 \%$ patients with GERD from the United Kingdom [31]. In
Chinese patients, MNBI was able to diagnose GERD with an AUROC of 0.721 , the best cut-off value was 1890.6 ohms [34]. Various cut-off values have been described for diagnosing GERD with variable accuracy which may be related to patient diet, ethnicity or apparatus used for measuring MNBI. Because of its high accuracy in assessing GERD with mostly high AUROC values, the use of MNBI could become an important tool in the diagnosis of GERD, however more studies are needed to confirm its diagnostic performance. Also, standard cut-off values need to be established for MNBI since most studies showed discrepancies between optimal cut-off values.

Another useful parameter that has been studied recently is the PSPW index. The PSPW index consists of identifying the efficiency of esophageal clearance by evaluating a primary peristaltic sequence triggered by reflux, which in turn triggers the delivery of salivary bicarbonate and epidermal growth factor in the distal esophagus in order to neutralize the acidic $\mathrm{pH}$ leading to the healing of lesions of the esophageal mucosa induced by acid reflux [24-26]. The PSPW index is defined as an anterograde 50\% decrease in impedance from the proximal region to all distal impedance sites. Also, the wave must appear 30 seconds after a reflux episode. PSPW index is calculated as the ratio between the total number of reflux episodes followed by PSPW and the total number of reflux episodes [23].

The PSPW index can differentiate between patients with erosive reflux disease and NERD, while also being able to differentiate both erosive reflux disease and NERD from functional heartburn $[23,26]$. Frazzoni et al. showed that PSPW was an excellent method of diagnosing GERD with AUROC 0.977 (CI 95\%, 0.961-0.993), while being more accurate than MNBI [24]. Erosive reflux disease can be assessed by PSPW with an accuracy of diagnosis of $97 \%$, while diagnosis of NERD can be established with an accuracy of $89 \%$ [24]. Both PSPW and MNBI seem to be superior to AET as a predictor of response to PPI treatment [35].

\section{CONCLUSIONS}

GERD is a complex disease with multiple phenotypes that may require multiple steps to correctly evaluate. While most patients respond to initial PPI trial, some require further investigations such as upper gastrointestinal endoscopy, conventional $\mathrm{pH}$-monitoring or MII-pH. 
MII-pH is the most useful method to distinguish between acid reflux and non-acid reflux. It can differentiate between non-erosive reflux disease, reflux hypersensitivity, functional heartburn and thus guide therapeutic management. New parameters in $\mathrm{pH}$ impedance such as the PSPW index and MNBI can help in evaluating the different phenotypes of GERD.

Boala de reflux gastroesofagian (GERD) este una dintre cele mai frecvente patologii cronice digestive în lume, implicând costuri crescute pentru tratament și investigații. În prima linie de terapie sunt inhibitorii de pompă de protoni, iar cei ce nu răspund la această terapie necesită endoscopie digestivă superioară și pH-metrie. Timpul total de expunere la acid și scorul DeMeester sunt cei mai importanți parametri atunci când evaluăm GERD.

Deși pH-metria este considerată standardul de aur în privința evaluării GERD, noi parametri bazați pe impedanță au fost introduși în ultimii ani pentru a crește acuratețea diagnosticării GERD. Dezvoltarea evaluării $p H$-impedanță intraluminală a îmbunătățit abilitatea de a detecta și de a cuantifica GERD. Noi parametri, cum ar fi indexul undei peristaltice post-deglutitie (PSPW - post-reflux swallowing peristaltic wave) și media impedanței bazale nocturne (MNBI), au fost introduși pentru a evalua cât mai corect fenotipurile GERD. Acest review trece în revistă instrumentele pe care le avem la dispoziție pentru a diagnostica GERD.

Correspondence to: Elena-Roxana Săraru, University Emergency Hospital Bucharest, Gastroenterology Department, 169 Splaiul Independentei, Sector 5, Bucharest, Romania; postal code: 050098

Tel./Fax: +40754241089

E-mail: elena.roxana2010@yahoo.com

Conflict of interest disclosure: The authors declare that there are not conflicts of interest.

\section{REFERENCES}

1. VAKIL N, VAN ZANTEN SV, KAHRILAS P, DENT J, JONES R. The Montreal definition and classification of gastroesophageal reflux disease: a global evidence-based consensus. The American journal of gastroenterology. 2006; 101(8):1900-20; quiz 43.

2. EL-SERAG HB, SWEET S, WINCHESTER CC, DENT J. Update on the epidemiology of gastro-oesophageal reflux disease: a systematic review. Gut. 2014; 63(6):871-80.

3. SHAHEEN NJ, HANSEN RA, MORGAN DR, GANGAROSA LM, RINGEL Y, THINY MT, et al. The burden of gastrointestinal and liver diseases, 2006. The American journal of gastroenterology. 2006; 101(9):2128-38.

4. KATZ PO, GERSON LB, VELA MF. Guidelines for the diagnosis and management of gastroesophageal reflux disease. The American journal of gastroenterology. 2013; 108(3):308-28; quiz 29.

5. YADLAPATI R, PANDOLFINO JE. Personalized Approach in the Work-up and Management of Gastroesophageal Reflux Disease. Gastrointest Endosc Clin N Am. 2020; 30(2):227-38.

6. JOHNSON LF, DEMEESTER TR. Twenty-four-hour pH monitoring of the distal esophagus. A quantitative measure of gastroesophageal reflux. The American journal of gastroenterology. 1974; 62(4):325-32.

7. HERBELLA FA, NIPOMINICK I, PATTI MG. From sponges to capsules. The history of esophageal pH monitoring. Diseases of the esophagus: official journal of the International Society for Diseases of the Esophagus. 2009; 22(2):99-103.

8. TUTTLE SG, GROSSMAN MI. Detection of gastro-esophageal reflux by simultaneous measurement of intraluminal pressure and $p H$. Proceedings of the Society for Experimental Biology and Medicine Society for Experimental Biology and Medicine (New York, NY). 1958; 98(2):225-7.

9. SAVARINO E, BREDENOORD AJ, FOX M, PANDOLFINO JE, ROMAN S, GYAWALI CP. Expert consensus document: Advances in the physiological assessment and diagnosis of GERD. Nat Rev Gastroenterol Hepatol. 2017; 14(11):665-76.

10. ROMAN S, GYAWALI CP, SAVARINO E, YADLAPATI R, ZERBIB F, WU J, et al. Ambulatory reflux monitoring for diagnosis of gastro-esophageal reflux disease: Update of the Porto consensus and recommendations from an international consensus group. Neurogastroenterology and motility: the official journal of the European Gastrointestinal Motility Society. 2017; 29(10):1-15.

11. JOBE BA, RICHTER JE, HOPPO T, PETERS JH, BELL R, DENGLER WC, et al. Preoperative diagnostic workup before antireflux surgery: an evidence and experience-based consensus of the Esophageal Diagnostic Advisory Panel. Journal of the American College of Surgeons. 2013; 217(4):586-97.

12. JOHNSON LF, DEMEESTER TR. Development of the 24-hour intraesophageal pH monitoring composite scoring system. J Clin Gastroenterol. 1986; 8 Suppl 1:52-8. 
13. NETO RML, HERBELLA FAM, SCHLOTTMANN F, PATTI MG. Does DeMeester score still define GERD? Diseases of the esophagus: official journal of the International Society for Diseases of the Esophagus. 2019; 32(5).

14. FRAZZONI M, DE BORTOLI N, FRAZZONI L, TOLONE S, SAVARINO V, SAVARINO E. Impedance-pH Monitoring for Diagnosis of Reflux Disease: New Perspectives. Digestive diseases and sciences. 2017; 62(8):1881-9.

15. HOBBS P, GYAWALI CP. The role of esophageal pH-impedance testing in clinical practice. Current opinion in gastroenterology. 2018; 34(4):249-57.

16. JAMIESON JR, STEIN HJ, DEMEESTER TR, BONAVINA L, SCHWIZER W, HINDER RA, et al. Ambulatory 24- $h$ esophageal pH monitoring: normal values, optimal thresholds, specificity, sensitivity, and reproducibility. The American journal of gastroenterology. 1992; 87(9):1102-11.

17. GYAWALI CP, KAHRILAS PJ, SAVARINO E, ZERBIB F, MION F, SMOUT A, et al. Modern diagnosis of GERD: the Lyon Consensus. Gut. 2018; 67(7):1351-62.

18. GHILLEBERT G, JANSSENS J, VANTRAPPEN G, NEVENS F, PIESSENS J. Ambulatory 24 hour intraoesophageal pH and pressure recordings $v$ provocation tests in the diagnosis of chest pain of oesophageal origin. Gut. 1990; 31(7):738-44.

19. SILNY J. Intraluminal Multiple Electric Impedance Procedure for Measurement of Gastrointestinal Motility. Neurogastroenterology \& Motility. 1991; 3(3):151-62.

20. FOROOTAN M, ZOJAJI H, EHSANI MJ, DARVISHI M. Advances in the Diagnosis of GERD Using the Esophageal pH Monitoring, Gastro-Esophageal Impedance-pH Monitoring, And Pitfalls. Open access Macedonian journal of medical sciences. 2018; 6(10):1934-40.

21. MARTINUCCI I, DE BORTOLI N, SAVARINO E, PIAGGI P, BELLINI M, ANTONELLI A, et al. Esophageal baseline impedance levels in patients with pathophysiological characteristics of functional heartburn. Neurogastroenterology and motility: the official journal of the European Gastrointestinal Motility Society. 2014; 26(4):546-55.

22. DE BORTOLI N, MARTINUCCI I, SAVARINO E, TUTUIAN R, FRAZZONI M, PIAGGI P, et al. Association between baseline impedance values and response proton pump inhibitors in patients with heartburn. Clinical gastroenterology and hepatology: the official clinical practice journal of the American Gastroenterological Association. 2015; 13(6):1082-8.e1.

23. FRAZZONI M, MANTA R, MIRANTE VG, CONIGLIARO R, FRAZZONI L, MELOTTI G. Esophageal chemical clearance is impaired in gastro-esophageal reflux disease - a 24-h impedance-pH monitoring assessment. Neurogastroenterology and motility: the official journal of the European Gastrointestinal Motility Society. 2013; 25(5):399-406, e295.

24. FRAZZONI M, SAVARINO E, DE BORTOLI N, MARTINUCCI I, FURNARI M, FRAZZONI L, et al. Analyses of the Postreflux Swallow-induced Peristaltic Wave Index and Nocturnal Baseline Impedance Parameters Increase the Diagnostic Yield of Impedance-pH Monitoring of Patients With Reflux Disease. Clinical gastroenterology and hepatology: the official clinical practice journal of the American Gastroenterological Association. 2016; 14(1):40-6.

25. FRAZZONI M, DE BORTOLI N, FRAZZONI L, FURNARI M, MARTINUCCI I, TOLONE S, et al. Impairment of chemical clearance and mucosal integrity distinguishes hypersensitive esophagus from functional heartburn. Journal of gastroenterology. 2017; 52(4):444-51.

26. FRAZZONI M, DE BORTOLI N, FRAZZONI L, TOLONE S, FURNARI M, MARTINUCCI I, et al. The added diagnostic value of postreflux swallow-induced peristaltic wave index and nocturnal baseline impedance in refractory reflux disease studied with on-therapy impedance-pH monitoring. Neurogastroenterology and motility: the official journal of the European Gastrointestinal Motility Society. 2017; 29(3).

27. WOODLAND P, AL-ZINATY M, YAZAKI E, SIFRIM D. In vivo evaluation of acid-induced changes in oesophageal mucosa integrity and sensitivity in non-erosive reflux disease. Gut. 2013; 62(9):1256-61.

28. KANDULSKI A, WEIGT J, CARO C, JECHOREK D, WEX T, MALFERTHEINER P. Esophageal intraluminal baseline impedance differentiates gastroesophageal reflux disease from functional heartburn. Clinical gastroenterology and hepatology: the official clinical practice journal of the American Gastroenterological Association. 2015; 13(6):1075-81.

29. VAN RHIJN BD, KESSING BF, SMOUT AJ, BREDENOORD AJ. Oesophageal baseline impedance values are decreased in patients with eosinophilic oesophagitis. United European gastroenterology journal. 2013; 1(4):242-8.

30. SAVARINO E, GEMIGNANI L, POHL D, ZENTILIN P, DULBECCO P, ASSANDRI L, et al. Oesophageal motility and bolus transit abnormalities increase in parallel with the severity of gastro-oesophageal reflux disease. Alimentary pharmacology \& therapeutics. 2011; 34(4):476-86.

31. HOSHIKAWA Y, SAWADA A, SONMEZ S, NIKAKI K, WOODLAND P, YAZAKI E, et al. Measurement of Esophageal Nocturnal Baseline Impedance: A Simplified Method. Journal of neurogastroenterology and motility. 2020; 26(2):241-7.

32. ZHANG M, PANDOLFINO JE, ZHOU X, TAN N, LI Y, CHEN M, et al. Assessing different diagnostic tests for gastroesophageal reflux disease: a systematic review and network meta-analysis. Therapeutic advances in gastroenterology. 2019; $12: 1756284819890537$.

33. RAVI K, GENO DM, VELA MF, CROWELL MD, KATZKA DA. Baseline impedance measured during high-resolution esophageal impedance manometry reliably discriminates GERD patients. Neurogastroenterology and motility: the official journal of the European Gastrointestinal Motility Society. 2017; 29(5).

34. SUN YM, GAO Y, GAO F. Role of Esophageal Mean Nocturnal Baseline Impedance and Post-reflux Swallow-induced Peristaltic Wave Index in Discriminating Chinese Patients With Heartburn. Journal of neurogastroenterology and motility. 2019; 25(4):515-20.

35. FRAZZONI L, FRAZZONI M, DE BORTOLI N, TOLONE S, FURNARI M, MARTINUCCI I, et al. Postreflux swallowinduced peristaltic wave index and nocturnal baseline impedance can link PPI-responsive heartburn to reflux better than acid exposure time. Neurogastroenterology and motility: the official journal of the European Gastrointestinal Motility Society. 2017; 29(11).

36. HAN MS, PETERS JH. Ambulatory Esophageal pH Monitoring. Gastrointestinal Endoscopy Clinics of North America. 2014; 24(4):581-94.

Received $17^{\text {th }}$ July 2020 